\title{
The Influence of Independence, Competence, Work Experience, and Professional Ethics on Auditor's Performance: Empirical Study Done to Public Accounting Firms in East Java
}

\author{
Aziza Shella Ade Yolandra ${ }^{1}$, Sumiadji ${ }^{2}$, Kuni Utami Handayawati ${ }^{3}$ \\ Diploma IV Program in Management Accounting \\ Polytechnic Negeri Malang \\ Indonesia
}

\begin{abstract}
This study explained the influence of independence, competence, work experience, and professional ethics on auditor's performance. Primary data were obtained from questionnaires distributed to auditors in Public Accounting Firm (KAP) in East Java as respondents. 100 samples were selected using Purposive Sampling Technique. It means all variables affect the auditor's performance individually. Based on the data analysis, independent variables including independence, competence, work experience and professional ethics had significant influence on auditor's performance. Independence was reflected in auditor's ability to uncover evidence-based findings, competence was indicated by auditors' understanding on clients' conditions based on Public Accountant Professional Standards (SPAP) and code of ethics, work experience was indicated by auditors' ability to make decisions with less errors, while Professional ethics was shown by auditors' ability to carry out responsibilities with regard to public interests rather than personal interests. This study was expected to provide valuable insights to the improvement of auditors' expertise and ability for better audit outcome.
\end{abstract}

Keywords: Independence, Competence, Work Experience. Professional ethics, Auditor's Performance.

\section{INTRODUCTION}

Auditor performance refers to the work performance of an auditor starting from audit planning, testing to the implementation, inspection, and audit reporting. Mulyadi [1] defined audit performance as the work carries out by a public accountant regarding certain assignment, objective examination of company's financial statements or other organization with the aim of determining whether the financial statements present fair information based on the generally accepted accounting principles in terms of every content, financial position and operational outcome of the company. Financial statement manipulation once occurred in Indonesia, involving Kimia Farma and Bank Lippo [2], and a case involving public accountants namely Kasner Sirumapea and Public Accounting Firm (KAP) Tanubrata, Susanto, Fahmi, Bambang, and Partners as auditors for the financial statements of PT Garuda Indonesia (Persero) Tbk. Sanctions weree given after the Ministry of Finance did an on-site investigation regarding Garuda Indonesia's financial statements of 2018 year.

Cintyaningsih [3] examined "The Influence of Experience, Competence, and Independence on Auditor Performance in Surabaya through Professionalism as an Intervening Variable", which results showed that experience, independence, and professionalism had no significant influence on auditor performance, while competence significantly influenced on auditor performance. Whereas, experience and competence did not influence auditor performance through professionalism. Hence professionalism was not an intervening variable between those two variables. Further, Putri and Saputra [4] examined "The Influence of Independence, Professionalism, and Professional Ethics on Auditor Performance in Public Accounting Firms in Bali”, confirming the significant influence of independence, professionalism and professional on auditor performance.

This present study was carried out to examine and analyze the influence of independence, competence, work experience and professional ethics on auditor performance (an empirical study of public accounting firms in East Java). Research problem was formulated as "The Effect of Independence, Competence, Work Experience and Professional Ethics on Auditor Performance (Empirical Study of Public Accounting Firms in East Java)". 


\subsection{Theoretical basis}

\section{a. Signaling Theory}

Signaling theory is closely related with information asymmetry. This theory states that the success or management delinquency can be passed directly to the owner. This theory shows that proper information delivery can distinct one company to those with poor information delivery. This concept deals with the need to provide company information to the market in order to see whether or not the company has good prospects in the future, which eventually will help strengthen the market confidence.

A manager should be motivated to immediately provide necessary information for the public through press conferences. The truth about the information is confidential to the company as the company has to sort out unnecessary information for public. Manager's role in convincing the public is an important duty for it determines the company's securities. Thus, it is obvious that asymmetric-information in signaling theory to investors and the public in general through management mechanisms is considered very important [5].

Jogiyanto [6] stated that information publication through formal announcement can generate direct signals to investors regarding their investment decision. When information is conveyed, investors will be able to directly interpret and analyze the information and decide whether the information is good signals (good news) or bad signals (bad news). Good news will improve investors' interests in making moves in stock trading. This market reaction brings changes in the volume of shares traded [7]. Financial statements are seen as good signals that companies can reveal to the public.

\section{b. Auditor's Performance}

Trisnaningsih [8] viewed work performance as a work achieved by a person in carrying out the tasks assigned to him based on skills, experience and seriousness by taking into consideration the quantity, quality and timeliness. Work performance can be measured through certain parameters, in which quality is related to the quality of work produced, while quantity deals with the load of work produced within a certain period of time, while timeliness is the punctuality of the task completion. The characteristic that distinguishes auditor performance from manager performance is on the output produced.

On the other hand, Fanani [9] stated that auditor's performance is expected to comply with predetermined standards within a certain period of time. The standards include (1) the definition of the quality of work makes the work completion should be based on overall abilities \& skills, which later will depend on auditors' knowledge; (2) the quantity of work completed is compared to the target as the form of auditor's job responsibility, along with the ability to optimize support facilities \& infrastructure; (3) preciseness of work Therefore, auditor's performance will be of particular concern to investors before making investment decision to certain company.

\section{c. Independence}

Within the context of this study, independence is defined as the attitude that is free from any intervention, either in the form of control, dependence or other intervention from outside parties. In this case, independence is closely related to auditor's honesty in making consideration to facts and being objectives from any bias either in making statements [10].

On the contrary, Hery [11] viewed independence as auditor's attitude in carrying out tasks independently. In this context, independent refers to free and objective attitude which is an important aspect in the assessment process that is bias-free.

\section{d. Competence}

Competence is related to adequate education and experience of a public accountant that are relevant to the field of auditing and accounting. An auditor must be someone who understands accounting and auditing with sufficient experience, which will improve auditor's performance [12]. In carrying out their duties, auditors must have the required competence in accounting and auditing in particular. Inadequate competence can affect the performance of auditors in carrying out their duties.

Thus, auditors' competences in carrying out auditing process should comply with the general standards called auditor competencies [13]. During the audit process, auditor must believe in virtue value, have strong relevant experiences, and should be supported by special expertise in this expertise. Auditing skills and knowledge are the main competencies required needed by an auditor. Such skills show auditor's comprehension of certain entity to be audited, supported by the ability to work together and proper problem analysis skill. 


\section{e. Work Experience}

Libby revealed in a research analysis written by Aini [14] that an auditor is a professional worker who employs specific expertise. Auditor's work experience is directly proportional to auditing outcome, problem solving, and the involvement in monitoring \& examination of internal control structure. Such experience can be obtained when completing the audit process correctly.

Singgih \& Bawono (2010) in Wardani [15] found that experience is a learning process and the development of ethics is assessed based on formal education process or non-formal education. However, good auditor has better ethics. Each decision proposed by an auditor is expected to be correct as seen from the empirical facts in the field and the decision should be based on vast work experience.

\section{f. Professional Ethics}

Firdaus defined ethics in research conducted by Fitriani [16] as a principle of values or norms. This principle is related to auditor's characteristics which is closely related to honesty, integrity, fulfillment of agreements, strong loyalty, just, caring for others, willingness to respect others, responsibility as a nation's citizen, and strive for the best results. In maintaining positive performance of auditors, standards of ethics should be enhanced.

\section{Correlation between Variables}

\section{Independence on Auditor Performance}

Fraud disclosure should be done based on empirical evidences found during investigation which will later improve auditor's performance. The results of research conducted by Gustia [17] showed that independence has a significant influence on auditor performance.

\section{COMPETENCE ON AUDITOR PERFORMANCE}

Every auditor who works in public accounting must understand and carry out his professional services based on Public Accountant Professional Standards (SPAP) to improve auditor performance. The results of research conducted by Fitriani [16] show that competence has a significant influence on auditor performance.

\section{WORK EXPERIENCE ON AUDITOR PERFORMANCE}

The longer the work experience, the more capable an auditor in detecting errors which can help the auditor to develop his performance. Mayasari [18] believes that work experience has a significant influence on auditor performance.

\section{PROFESSIONAL ETHICS ON AUDITOR PERFORMANCE}

In carrying out professional duties, an auditor carries out the stages of auditing financial statements based on the technical standards and professional code of ethics to improve auditor performance. Nugraha and Ramantha [19] confirmed that professional ethics has a significant impact on auditor performance.

\section{Hypotheses}

Gustia [17] and Alnoprika M [20] found empirical evidence that independence has a significant influence on auditor performance. An auditor must be a person who is not easily intervened by anyone in carrying out investigation of client's financial statements.

$\mathrm{H}_{1}$ : Independence has a positive and significant influence on Auditor Performance

Alnoprika [20] and Fitriani [16] found empirical evidence that competence significantly affects auditor performance. An auditor must be a person who understands accounting and auditing, and have attended training and certification tests in order to improve the performance.

$\mathrm{H}_{2}$ : Competence has a positive and significant influence on Auditor Performance. 
Mayasari [18] found empirical evidence that work experience has a significant influence on auditor performance. Auditors with strong experience will be more productive in carrying out their works and they are capable in solving the problems faced so that the performance achieved will be maximized.

$\mathrm{H}_{3}$ : Work Experience has a positive and significant influence on Auditor Performance.

Putri and Saputra [4], Gustia [17], Alnoprika [20] Nugraha and Ramantha [19], and Mayasari [18] have found empirical evidences that professional ethics has a significant influence on auditor performance. Auditors who adhere the professional ethics will carry out their professional duties that will improve auditor performance.

$\mathrm{H}_{4}$ : Professional Ethics has a positive and significant influence on Auditor Performance.

\section{Method}

\section{Approach/Design of the Study}

This quantitative study regarded primary data which were collected from questionnaires distributed in public accounting firms in East Java with partner respondents, managers, supervisors, senior auditors, and junior auditors.

\section{Population and Samples}

The population of this research included all auditors working at Public Accounting Firms (KAP) in Surabaya and Malang, East Java amounting to 208 auditors. Samples of this study included auditor performance in working for JAP Surabaya and Malang, The respondents of this study were 100 auditors.

\section{Subjects of the Study}

The subjects of this study were auditors working public accounting firm including partners, managers, supervisors, senior auditors, and junior auditors.

\section{Data Collection}

This study was conducted in the form of a survey, in which data were obtained from questionnaires distributed directly to auditors working in Public Accounting Firm (KAP) in East Java.

\section{Data Analysis Method}

The obtained data were analyzed using multiple linear regression and tests including descriptive statistics, validity and reliability tests, classical assumption tests, and hypothesis testing.

\section{Operational Definition and Measurement of the Variables}

Auditor performance was measured using an instrument adopted by researcher from Eviyany and Lapoliwa [21]. Independence was measured using an instrument developed by researchers from Wahyuni instrument [22]. Competence was measured using instruments developed by researchers [23]. Work experience was measured using an instrument adapted by researchers [24]. Finally, professional ethics was measured using an instrument developed by researchers [22].

\section{RESULTS AND DISCUSSIONS}

\section{The Results of Descriptive Analysis Measurement}

The results of the descriptive analysis showed that $38 \%$ of the respondents aged 25, and the sex proportion was 50:50. Most respondents (70\%) held bachelor's degree, and junior accountants dominated by $36 \%$. More than half of the respondents $(57 \%)$ had not yet finished accounting profession education, and most of them attended 1-2 trainings (33\%). 52\% of them have found fraud, and most of them (53\%) had been working for 2 to 5 years and mostly had been assigned for more than 10 times (41\%). Based on the instrument, auditor performance obtained a minimum value of 20, a maximum value of 50, an average value (mean) of 35.38, and a standard deviation of 7.35. For Independence variable, the minimum value was 19 , a maximum value of 45, an average value (mean) of 31.18 , and a standard deviation of 6.41 . Competence showed a minimum value of 12 , a maximum value of 30 , an average value (mean) of 21.28 , and a standard deviation of 4.44 . Work experience had a minimum value of 14 , a maximum value of 35 , an average value (mean) of 24.65, and a standard deviation of 5.03. Finally, professional ethics obtained a minimum value of 28, a maximum value of 67, an average (mean) value of 49.22, and a standard deviation of 9.50 . 


\section{The Results of Data Quality Measurement}

The results of the validity test consisting of 10 (ten) questions for Auditor Performance (Y), 9 (nine) questions for Independence (X1), 6 (six) questions for Competence (X2), 7 (seven) questions for Experience Work (X3), and 14 (fourteen) questions for Professional Ethics (X4), it is known that the value of Validity Coefficient> Critical Point (0.195) for each variable, indicating that all data were valid.

Regarding the reliability test, it can be seen that the instrument reliability coefficients include Auditor Performance of (0.954), Independence of (0.903), Competence of (0.917), Work Experience of (0.909), and Professional Ethics of (0.937). Cronbach's Alpha value was > 0.6, indicating that the questionnaire used to collect data regarding auditor performance variables, independence, competence, work experience and professional ethics is reliable or trustworthy.

\section{Results of Classic Assumption Test}

\section{Normality Test}

\section{Table 1 List of the Normality Test}

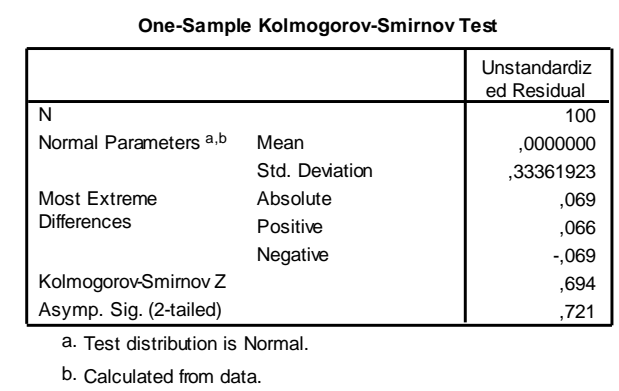

h Asymptotic Significances was found at $0.721>0.05$. Therefore, the regression model proposed in this study have fulfilled the normality assumption.

\section{Multicollinearity Test}

Table 2 List of Multicollinearity Test

\begin{tabular}{|c|c|c|c|c|c|c|}
\hline \multicolumn{7}{|c|}{ Coefficients $^{\mathrm{a}}$} \\
\hline \multirow[b]{2}{*}{ Model } & & \multicolumn{2}{|c|}{$\begin{array}{l}\text { Unstandardized } \\
\text { Coefficients }\end{array}$} & \multirow{2}{*}{$\begin{array}{c}\text { Standardized } \\
\text { Coefficients } \\
\text { Beta }\end{array}$} & \multirow[b]{2}{*}{$t$} & \multirow[b]{2}{*}{ Sig. } \\
\hline & & $B$ & Std. Error & & & \\
\hline 1 & (Constant) & ,116 & ,185 & &, 625 & 533 \\
\hline & Independensi (X1) & , 189 & ,092 & 184 & 2,057 & ,042 \\
\hline & Kompetensi (X2) & 270 &, 103 &, 277 & 2,627 & 010 \\
\hline & Pengalaman Kerja (X3) & 265 &, 113 & 259 & 2,350 & .021 \\
\hline & Etika Profesional $(X 4)$ & ,250 & , 120 & ,231 & 2,085 & ,040 \\
\hline
\end{tabular}

a. Dependent Variable: Kineria Auditor $(Y)$

VIF value for all independent variable was $<10$ with a tolerance value of $>0,10$. Hence, the regression model contains no multicollinearity.

\section{Autocorrelation Test}

Table 3 List of Autocorrelation Test

\section{Model Summary}

\begin{tabular}{|l|r|}
\hline Model & $\begin{array}{c}\text { Durbin- } \\
\text { Watson }\end{array}$ \\
\hline 1 & 2,179 \\
\hline
\end{tabular}

Durbin-Watson score was found at 2.179, implying that no autocorrelation occurred in the regression equation used in this study since the Durbin-Watson score was between du and 4-du. 


\section{Heteroscedasticity Test}

Table 4 List of Heteroscedasticity Test

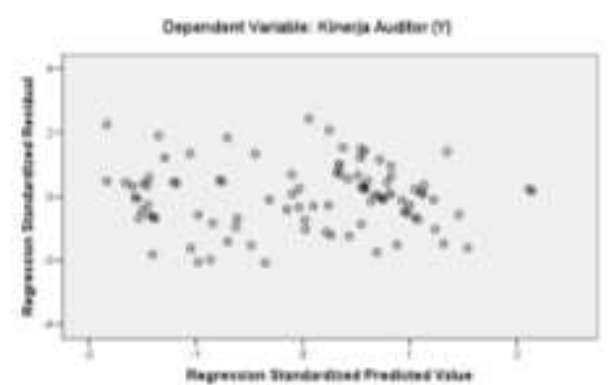

As shown in the scatterplot, dots are evenly scattered around 0 , indicating no heteroscedasticity occurred in the regression model.

\section{Results of Hypotheses Testing}

Table 5 Results of Partial Testing of Each Hypothesis

\begin{tabular}{|c|c|c|c|c|c|c|}
\hline \multicolumn{7}{|c|}{ Coefficients $^{\mathrm{a}}$} \\
\hline \multirow[b]{2}{*}{ Model } & & \multicolumn{2}{|c|}{$\begin{array}{l}\text { Unstandardized } \\
\text { Coefficients }\end{array}$} & \multirow{2}{*}{$\begin{array}{c}\text { Standardized } \\
\text { Coefficients }\end{array}$} & \multirow[b]{2}{*}{$t$} & \multirow[b]{2}{*}{ Sig. } \\
\hline & & $B$ & Std. Error & & & \\
\hline 1 & (Constant) & 116 & 185 & &, 625 &, 533 \\
\hline & Independensi (X1) & 189 & 092 & 184 & 2,057 & ,042 \\
\hline & Kompetensi (X2) & 270 & 103 & 277 & 2,627 & 010 \\
\hline & Pengalaman Kerja (X3) & 265 & 113 & 259 & 2,350 & 021 \\
\hline & Etika Profesional (X4) & ,250 & , 120 & ,231 & 2,085 & ,040 \\
\hline
\end{tabular}

Source: Data processed using SPSS 25.0 (2020)

\section{DISCUSSIONS}

\section{Test of the First Hypothesis}

The first hypothesis testing was done to test whether independence affects auditor performance. Table 4 shows that the significant value was $0.042<0.05$, meaning that independence significantly influenced auditor performance.

At significance level $0.042<0.05$, the influence of independence on auditor performance was positive. Stronger independence will be likely followed by better auditor performance in carrying out their responsibilities, and vice versa.

This results are in line with the results of research by Putri and Saputra [4], Gustia [17], and Alnoprika [20] who found that independence has a positive and significant influence on auditor performance. The higher the independence of an auditor, the higher the auditor performance will be.

\section{Test of the Second Hypothesis}

The second hypothesis tested whether competence affects auditor performance. The significant value of $0.010<0.05$ presented in Table 4 shows that competence has a significant influence on auditor performance.

With a significance of $0.010<0.05$, the influence was positive and significant. Thus, the higher the competence of an auditor, the higher the performance in carrying out responsibilities, vice versa.

The results of this study support Alnoprika M [20] who also found that competence has a positive and significant influence on auditor performance. Higher competence of an auditor will be followed by higher performance.

\section{Test of the Third Hypothesis}

The third hypothesis tested whether work experience has an influence on auditor performance. The significant value at 0.021 $<0.05$ indicates that work experience has a significant influence on auditor performance. 
With a significance value of $0.021<0.05$, the influence of work experience on auditor performance is positive and significant. Thus, the higher the work experience of an auditor, the higher the performance of the auditors in carrying out their responsibilities, vice versa.

Similarly, Mayasari [18] also found that work experience has a positive and significant influence on auditor performance. The higher the work experience of an auditor, the higher the auditor's performance.

\section{Test of the Fourth Hypothesis}

The fourth hypothesis tested if professional ethics influences auditor performance. As presented in Table 4, the significant value of $0.040<0.05$ shows that professional ethics has a significant influence on auditor performance.

With a significance of $0.040<0.05$, the influence of professional ethics on auditor performance is positive and significant. Therefore, the higher the professional ethics of an auditor, the higher the performance of the auditors in carrying out their responsibilities, vice versa.

The results of this study support Putri and Saputra [4], Gustia [17], Alnoprika [20], Nugraha and Ramantha [19], and Mayasari [18] who found that professional ethics has a positive and significant infleunce on auditor performance. The higher the professional ethics of an auditor, the higher the auditor's performance.

\section{IMPLICATIONS}

\section{Recommendations}

1. The data showed that the experience obtained the lowest score while it actually supports the task completion. Thus, auditors' experience should be enhanced through training, formal education, and courses in auditing.

2. Auditors are expected to strengthen their independence by ensuring that they can objectively state their opinions to their clients.

3. Auditors are encouraged to expand their work experience in order to be more capable in detecting errors and in providing proper recommendation in correcting the errors.

4. Auditors need to always comply with the professional ethics as determined by Ikatan Akuntan Publik Indonesia (IAPI).

\section{Significance of this Study}

\section{For Public Accounting Firms}

This study provides useful information regarding factors affecting auditor performance in Public Accounting Firms which can give valuable insights in making investment decisions.

\section{For Researchers}

This study provokes scientific thinking of researchers which eventually adds to the body of knowledge and competence in the field of accounting, particularly in the field of auditing.

\section{Limitations of the Study}

1. The scope of this study was limited to only Surabaya and Malang.

2. This study involved 4 variables (independence, competence, work experience, and professional ethics)

\section{CONCLUSIONS}

This study analyzed the influence of independence, competence, work experience, and professional ethics on auditor performance in Public Accounting Firms (KAP), East Java. Based on the results of the analysis and discussion of this study, independence, competence, work experience, and professional ethics have partial positive and significant influence on auditor performance

\section{REFERENCES}


[1] Mulyadi. 2013. Sistem Akuntansi. Jakarta: Salemba Empat.

[2]Wijayanto. 2015. Kearifan Lokal dalam Praktik Bisnis di Indonesia. Retrieved from http://kroniksastradanbudaya.blogspot.co.id/2015/02/kearifan-lokal-dalam-praktik-bisnis-di.html.

[3] Cintyaningsih, A. 2015. Pengaruh Pengalaman, Kompetensi dan Independensi Terhadap Kinerja Auditor di Surabaya dengan Profesionalisme Sebagai Variabel Interverning (Unpublished Thesis). Sekolah Tinggi Ilmu Ekonomi Perbanas Surabaya, Indonesia.

[4] Putri, K. M. d., \& Saputra, I. D. G. D. 2013. Pengaruh Independensi, Profesionalisme, dan Etika Profesi terhadap Kinerja Auditor Pada Kantor Akuntan Publik di Bali. E-Jurnal Akuntansi Universitas Udaya, 4(1), 39-53.

[5] Atmaja, L. S. 2008. Teori \& Praktik Manajemen Keuangan. Yogyakarta: Penerbit Andi.

[6] Jogiyanto. 2014. Analisis dan Desain Sistem Informasi, Sistem Informasi: Pendekatan Terstruktur Teori dan Praktik Aplikasi Bisnis. Yogyakarta: Andi Offset.

[7] Suwardjono. 2010. Teori Akuntansi: Pengungkapan dan Sarana Interpretatif. Yogyakarta: BPFE.

[8] Trisnaningsih, S. 2007. Independensi Auditor Dan Komitmen Organisasi Sebagai Mediasi Pengaruh Pemahaman Good Governance, Gaya Kepemimpinan Dan Budaya Organisasi Terhadap Kinerja Auditor. Jurnal Akuntansi Volume, 2(2), 1-56.

[9] Fanani, Z. 2008. Pengaruh Struktur Audit, Konflik Peran dan Ketidakjelasan Peran Terhadap Kinerja Auditor. Jurnal Akuntansi dan Keuangan Indonesia Volume, 5(2).

[10] Mulyadi. 2016. Sistem Akuntansi. Jakarta: Salemba Empat.

[11] Hery. 2010. Potret Profesi Audit Internal (Di Perusahaan Swasta dan BUMN Terkemuka). Bandung: Alfabeta.

[12] Sunu, G. G. W. (2013). Kompetensi, Independensi, Pemahaman Sistem Informasi Akuntan dan Kinerja Auditor BPK. E-Jurnal Akuntan Universitas Udayana.

[13] Jaeni, A. B. 2018. Faktor-faktor Yang Berpengaruh Terhadap Kualitas Audit Auditor Independensi Pada Kantor Akuntan Publik (Kap) Di Jawa Tengah. Dinamika Keuangan dan Perbankan, 3(2), 183-197.

[14] Aini, N. 2009. Pengaruh Independi, Pengalaman Auditor dan Etika Auditor Terhadap Kualitas Audit (Unpublished Thesis). UIN Syarif Hidayatullah, Jakarta.

[15] Wardani, Amalia. 2013. Pengaruh Independensi, Pengalaman, Due Professional Care, dan Akuntabilitas terhadap Kualitas Audit (Studi Empiris pada KAP Wilayah Surakarta dan Yogyakarta). Skripsi. Fakultas Ekonomi dan Bisnis Universitas Muhammadiyah Surakarta.

[16] Fitriani. 2016. Pengaruh Pengalaman Kerja, Kompetensi, Independensi, Due Professional Care dan Etika Auditor Terhadap Kualitas Audit (Studi Empiris Pada Auditor Inspektorat Kabupaten Boyolali dan Surakarta) (Unpublished Thesis). Universitas Muhamadiyah Surakarta, Indonesia.

[17] Gustia, N. 2014. Pengaruh Independensi Auditor, Etika Profesi, Komitmen Organisasi, dan Gaya Kepemimpinan Terhadap Kinerja Auditor Pemerintah (Studi Empiris pada Auditor Pemerintah di BPKP Perwakilan Sumbar). Artikel Ilmiah. Padang.

[18] Mayasari, D. 2018. Pengaruh Pengalaman, Otonomi, Etika Profesi, Pelaksanaan Tanggung Jawab, dan Stress Kerja terhadap Kinerja Auditor (Studi Empiris pada KAP di Semarang) (Unpublished Thesis). Fakultas Ekonomi dan Bisnis Universitas katolik Soegijapranata, Semarang.

[19] Nugraha, I. D. S. A., \& Ramantha, I. W. 2015. Pengaruh Profesionalisme, Etika Profesi dan Pelatihan Auditor terhadap Kinerja Auditor Pada Kantor Akuntan Publik di Bali. E-Jurnal Akuntansi Universitas Udayana, 13(3), 916-943.

[20] Alnoprika, M. 2015. Pengaruh Kompetensi, Independensi, dan Profesionalisme Auditor terhadap Kinerja Auditor dengan Etika Sebagai Variabel Moderating (Studi pada Kantor Akuntan Publik di Pekanbaru, Batam, dan Medan). Jurnal. Jom FEKON, 2(1).

[21] Eviyany, A., \& Lapoliwa, N. 2014. Pengaruh Independensi, Integritas, dan Kompetensi Terhadap Kinerja Auditor. Ultima Accounting, 6(2).

[22] Wahyuni, A. S. 2017. Pengaruh Independensi, Etika Profesi dan Integritas Auditor Terhadap Kualitas Audit di Kantor Akuntan Publik Wilayah Daerah Istimewa Yogyakarta (Unpublished Thesis). Fakultas Ekonomi Universitas Negeri Yogyakarta, Indonesia.

[23] Azrina, R. 2016. Pengaruh Kompetensi, Independensi, Etika Profesi dan Pengalaman Auditor Terhadap Kualitas Audit Pada Perwakilan Badan Pengawasan Keuangan dan Pembangunan (Unpublished Thesis). Fakultas Ekonomi dan Bisnis, Medan.

[24] Dewi, A. J. 2016. Pengaruh Pengalaman Kerja, Kompetensi, dan Independensi terhadap Kualitas Audit dengan Etika Auditor sebagai Variabel Moderasi (Studi Empiris Auditor Internal pada Inspektorat Provinsi Daerah Istimewa Yogyakarta) (Unpublished Thesis). Fakultas Ekonomi Universitas Negeri Yogyakarta, Indonesia. 
International Journal of Advances in Scientific Research and Engineering (ijasre), Vol 6 (9), September -2020 